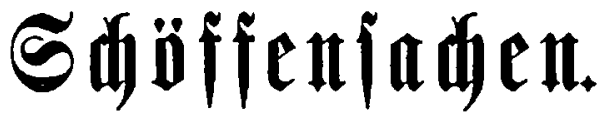

\section{Bufanmenftellung /ämmtlider}

im Beltungäberei

vor ben Sdjffengeriđten

fur Inmenbung tommenben

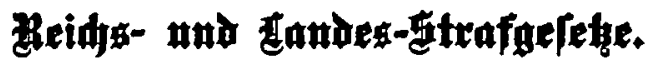

Thit befonberer Berüđjịtigung

ber

In Der Brobing Orandenburg und pezicll im Fiegierungs= bezirt Potsoam

erlaffenen Bolizeiberorbnungen

erläutert unb herausgegeben

bon

(b. Gethhazu,

gimtoridter in equebt.

Perlin und Reipzig.

Berlag von S. Fruttentag

(D. (5olin).

1881. 
